\title{
Tekne Turları Kapsamında Rekreasyonel Taşıma Kapasitesinin Belirlenmesine Yönelik Bir Yöntem Yaklaşımı: Beyşehir Gölü Milli Parkı Örneği
}

\author{
Tendü Hilal GÖKTUĞ ${ }^{1}$, Nihan YENILMEZ ARPA ${ }^{2}$ \\ ${ }^{1}$ Adnan Menderes Üniversitesi, Ziraat Fakültesi Peyzaj Mimarlığı Bölümü, Aydın \\ ${ }^{2}$ Orman ve Su İşleri Bakanlığı, Doğa Koruma ve Milli Parklar Genel Müdürlüğü, Ankara
}

Geliş (Received): 24.11.2015

Kabul (Accepted): 28.01.2016

\begin{abstract}
ÖZET: Milli parklar, sahip oldukları doğal ve kültürel öğelerinin bir araya getirdiği özgün karakterleri ile ilişkili olarak sürdürülebilirlik ilkesi çerçevesinde çok çeşitli rekreasyonel imkânlar sunmaktadırlar. Bu imkânlardan biri olan tekne turları ise her geçen gün daha fazla ziyaretçi tarafından talep edilmekte ve yöre halkı için geçim kaynağı oluşturan önemli bir sektör haline dönüşmektedir. Ancak sektördeki plansız büyüme, deniz, göl, kıyı ve kara ekosistemlerinde bozulmalara, rekreasyon kalitesinde düşüşlere ve ayrıca ekonomik yapıda zayıflamaya zemin hazırlamaktadır. Çalışmada, Beyşehir Gölü Milli Parkı'nda düzenlenen tekne turlarının sürdürülebilirliğinin sağlanması yönünde kara, kıyı, deniz ve göl alanlarına yönelik metodolojiler bütünleștirilerek, birbirleri ile etkileşim içerisinde olan göl ve adalardaki rekreasyonel kullanım alanlarının taşıma kapasitelerinin değerlendirilmesi amaçlanmıştır. Çalışmada göl, kıyı ve kara rekreasyon alanlarının Fiziksel Taşıma Kapasitesi (FTK), Gerçek Taşıma Kapasitesi (GTK) ve Etkin Taşıma Kapasitesi (ETK) bütünleştirilerek hesaplanmış, elde edilen değerler planlama ve yönetim kapsamında yorumlanarak ekolojik ve ekonomik sürdürülebilirliğin sağlanması yönünde öneriler sunulmuştur.
\end{abstract}

Anahtar Kelimeler: Rekreasyonel Taşıma Kapasitesi, Korunan Alanlar, Sürdürülebilir Turizm, Beyşehir Gölü Milli Parkı

\section{A Method Approach for Determining Recreational Carrying Capacity in the Scope of Boat Tours: Sample of Beyşehir Lake National Park}

\begin{abstract}
National parks, which have the natural and cultural elements that brought together as the original characters, offer a wide variety of recreational opportunities within the framework of the sustainability policy. The boat tours which one of these opportunities, demanded by more visitors each passing day and becoming an important sector, which is a source of livelihood for the local people. However, unplanned growth in the sector trigger the sea, lake and land degradation in coastal ecosystems, decline in quality recreation and also triggered a weakening of the economic structure. In this study, assessing the carrying capacity of recreation and boat using areas which interact with each other is aimed. In this context, the methodology approaches about carrying capacity of terrestrial, coastal, marine and lacustrine area are integrated. In the study, Physical Carrying Capacity (PCC), Reel Carrying Capacity (RCC), Effective Carrying Capacity (ECC) was calculated with integrating the coastal and rural recreation areas. The results obtained from calculation interpreted within the scope of planning and management and offer suggestions in terms of ensuring ecological and economic sustainability.
\end{abstract}

Key Words: Recreational Carrying Capacity, Protected Areas, Sustainable Tourism, Beyşehir Lake National Park

\section{GİRIS}

Milli Parklar, bilimsel ve estetik bakımından, ulusal ve uluslararası ender bulunan doğal ve kültürel kaynak değerlerine sahip halka açık tabiat parçaları olup, yönetimindeki ana amaç ise, kaynak değerlerinin korunması ve aynı zamanda ziyaretçilere yönelik çeşitli rekreasyon ve turizm olanaklarının sağlanmasıdır (Anonim, 1983). Bu olanaklardan biri olan tekne turları ise, deniz veya göl ekosistemine sahip olan milli parklarda her geçen gün daha fazla ziyaretçi tarafından talep edilmekte ve yöre halkı için geçim kaynağ oluşturan önemli bir sektör haline dönüşmektedir (Davenport ve Davenport, 2006; Hall, 2001; Friedlander, 2008). Ancak diğer aktivitelerde olduğu gibi, tekne turları kapsamında gerçekleştirilen yoğun rekreasyonel kullanımlar, kara, deniz ve göl ekosistemlerinde bozulmalara, ekonomik yapıda zayıflamaya ve ayrıca ziyaretçilerin rekreasyon deneyim kalitesinde düşüşler yaşanmasına neden olmaktadır. Bu bağlamda kaynağın ve faaliyetin sürdürülebilirliği yönünde, doğru bir planlama ve yönetim yaklaşımı geliştirebilmek için ideal biyofiziksel ve sosyal şartların sağlanması yönünde rekreasyonel taşıma kapasitesi analizleri ile kullanım limitinin eşik değerinin belirlenmesi önem taşımaktadır. Rekreasyonel taşıma kapasitesi korunan bir alanın doğal ve kültürel kaynak değerlerinde, ziyaretçi memnuniyetinde ve hizmet kalitesinde düşüşler yaşanmaksızın park yönetimince izin verilebilecek ziyaretçi kullanım miktarını ifade etmekte olup, konu son 50 y1l içerisinde fiziksel, yönetimsel, sosyal ve ekolojik boyutlarda irdelenmiștir (Shelby ve Heberlein, 1984; Göktuğ ve ark., 2013).

Fazla sayıdaki teknelerin ve yoğun olarak düzenlenen tekne turlarının çoğunlukla deniz veya göl ortamları üzerindeki biyofiziksel etkileri incelenmiş olup, tekne çapalarının özellikle deniz çayırlarına zarar 
verdiği (Dinsdale ve Harriott, 2004; Turner ve ark., 1997; Davenport ve Davenport, 2006; Lloret ve ark., 2008; West et al., 2002; Widmer ve Underwood, 2004), yoğun tekne turları ile deniz ve göllerde katı atık kirliliğinin ve (Abu-Hilal ve Al-Najjar, 2004), su kirliliğin arttığı (Crawford ve ark., 1994; Leon ve Warnken, 2008; Warnken ve ark., 2004), deniz hayvanlarında yaralanma ve davranış bozukluklarının meydana geldiği (Bejder ve ark., 2006; Nowacek ve Wells, 2001; Preen, 2000), gürültü kirliliğine sebep olduğu (Davenport ve Davenport, 2006; Lloret ve ark., 2008) belirtilmiştir. Ayrıca taşıma kapasitesi sosyal boyutta ele alınarak tekne sayılarının kalabalık algısı üzerindeki etkileri ve ziyaretçilerin güvenlik kaygılarını belirlemeye yönelik çalışmalar gerçekleştirilmiştir (Needham ve ark., 2011; Smallwood ve Beckley, 2008; Tarrant ve English, 1996; Brouwer ve ark., 2001; Falk ve Gerner, 2002; Kuentzel ve Heberlein, 2003, Manning ve ark., 1996; Tseng ve ark., 2009; Valliere ve Manning 2008). Tekne turları kapsamında, adalarda gezinti veya yüzme amaçlı molalar da verilmektedir. $\mathrm{Bu}$ sebeple yoğun ve plansız olarak sürdürülen tur tekneciliği faaliyeti, deniz ve göl ekosistemlerinin yanı sıra kara ve kıyı ekosistemi üzerinde de negatif etkilere sebep olmaktadır. Yürüyüş yollarının ve patikaların aşırı kullanımı sonucunda vejetasyon kapalılığında ve tür çeşitliliğinde azalmaların olduğu, topraktaki organik madde miktarı düşerken toprak sıkışmasının $\operatorname{arttığ~}$ belirtilmiştir (Adkison ve Jackson, 1996; Cole, 1987; Cole ve Bayfield, 1993; Farrell ve Marion, 2001; Hall ve Kuss, 1989; Kissling ve ark., 2009; Kobayashi ve ark., 1997; Kuss ve Grafe, 1985; Marion ve Leung, 2001; Whinam ve Chilcott, 1999). Sosyal taşıma kapasitesinin belirlenmesine yönelik çalışmalarda ise, ziyaretçilerin birbirleri ile karşılaşma sıklığının ve karşılaşan grupların büyüklüğünün kalabalık algısı üzerinde önemli etkileri olduğu vurgulanmış, (Stankey ve McCool 1984, Arnberger ve Haider 2007) optimum kabul edilebilir kullanım düzeyinin belirlenmesine yönelik çalışmalar gerçekleştirilmiştir (Lawson ve ark., 2003; Lawson ve ark., 2006; Manning ve ark., 2002; Stewart ve Cole, 2001; Manning ve ark., 2005; Manning ve ark., 2006). Tüm bu çalışmalarla birlikte, göllerde ve denizlerde rekreasyonel taşıma kapasitesinin eşik değerinin belirlenmesine yönelik olarak gerçekleştirilen akademik çalışmalar ise sınırlı sayıdadır (Turner ve Nielsen,1998; Cummins ve ark., 2008; Kopke ve ark., 2008; Progressive, 2001; Progressive, 2005; Rajan ve Varghese 2011; Doshi, 2006; Bosley, 2005).
Çalışmalarda taşıma kapasitesinin eşik değerinin belirlenmesinin oldukça karmaşık ve güç olduğu ifade edilmiştir. Bunun sebebi; bir gölün veya denizin rekreasyonel taşıma kapasitesinin eşik değeri, tek bir faktöre bağımlı olmayıp, gölün veya denizin fiziksel özellikleri, kullanım özellikleri (erişilen ada sayısı ve ada özellikleri, rekreasyonel faaliyetin tipi ve süresi), çevresel etkiler, ekolojik özellikler, kullanılabilir göl veya deniz alanının büyüklüğü, tekne hızı ve iklimsel özellikler gibi çok sayıda farklı faktörlere bağımlı oluşundan kaynaklanmaktadır (Mahoney ve Stynes 1995; Rajan ve Varghese, 2011).

Ülkemizde, milli parklarda ziyaretçi yönetimi ve taşıma kapasitesi analizleri ile ilgili çalışmaların geçmişi oldukça yenidir ve ulusal literatürlerde göllerde tekne taşıma kapasitesi analizlerine yönelik çalışmaya rastlanmamıştır. Ayrıca uluslararası literatürler incelendiğinde göl alanlarında tekne taşıma kapasitesi analizlerinde sadece göl alanının fiziksel özelliklerinin incelendiği saptanmıştır. Oysaki tekne turlarında 3 farklı rekreasyonel aktivite olan gölde tekne gezentisi, kıyıda yüzme ve güneş banyosu ile adada yürüyüş faaliyeti bir arada gerçekleşmekte olup birbirleri ile etkileşim halindedir. Çalışma alanı olarak belirlenen Beyşehir Gölü Milli Parkı'nda düzenlenen rekreasyonel amaçlı tekne turlarının sadece ekonomik değil aynı zamanda ekolojik ve sosyal sürdürülebilirliğinin sağlanması yönünde göl ve adalardaki rekreasyonel kullanım alanlarının bütünleşik bir şekilde ele alınarak optimum tekne ve ziyaretçi sayısının belirlenmesi gerektiği düşünülmektedir. Bu çalışmada; Beyşehir Gölü'nün rekreasyonel taşıma kapasitesinin belirlenmesi ve göl ile kara alanlarının kapasite analizlerinin bütünleştirilmesi yönüyle metodolojiye katkı sağlanması amaçlanmıştır.

\section{MATERYAL ve YÖNTEM}

Çalışma Alanı: Beyşehir Gölü Milli Parkı, İç Anadolu Bölgesi'nde, Konya ili sınırları dâhilinde, $8^{\circ}$ $125^{\prime}$ kuzey ile $37^{\circ} 50^{\prime}$ güney enlemi, $31^{\circ} 125^{\prime}$ batı ile $32^{\circ} 25^{\prime}$ doğu boylamı coğrafik koordinatları arasındadır (Şekil 1). Beyşehir Gölü Milli Parkı, 1993 yılında milli park ilan edilmiş olup, Beyşehir Gölü ve yakın çevresi ile birlikte 88750 ha'lık bir alanı kapsamaktadır. Milli Parkın 68.893 hektarlık bölümünü Beyşehir Gölü'nün Konya İl sınırları içerisinde yer almaktadır. Beyşehir Gölü'nün Isparta il sınırları içerisinde kalan kesimi ise Kızıldağ Milli Parkı sınırları içerisindedir (Anonim 2001). 


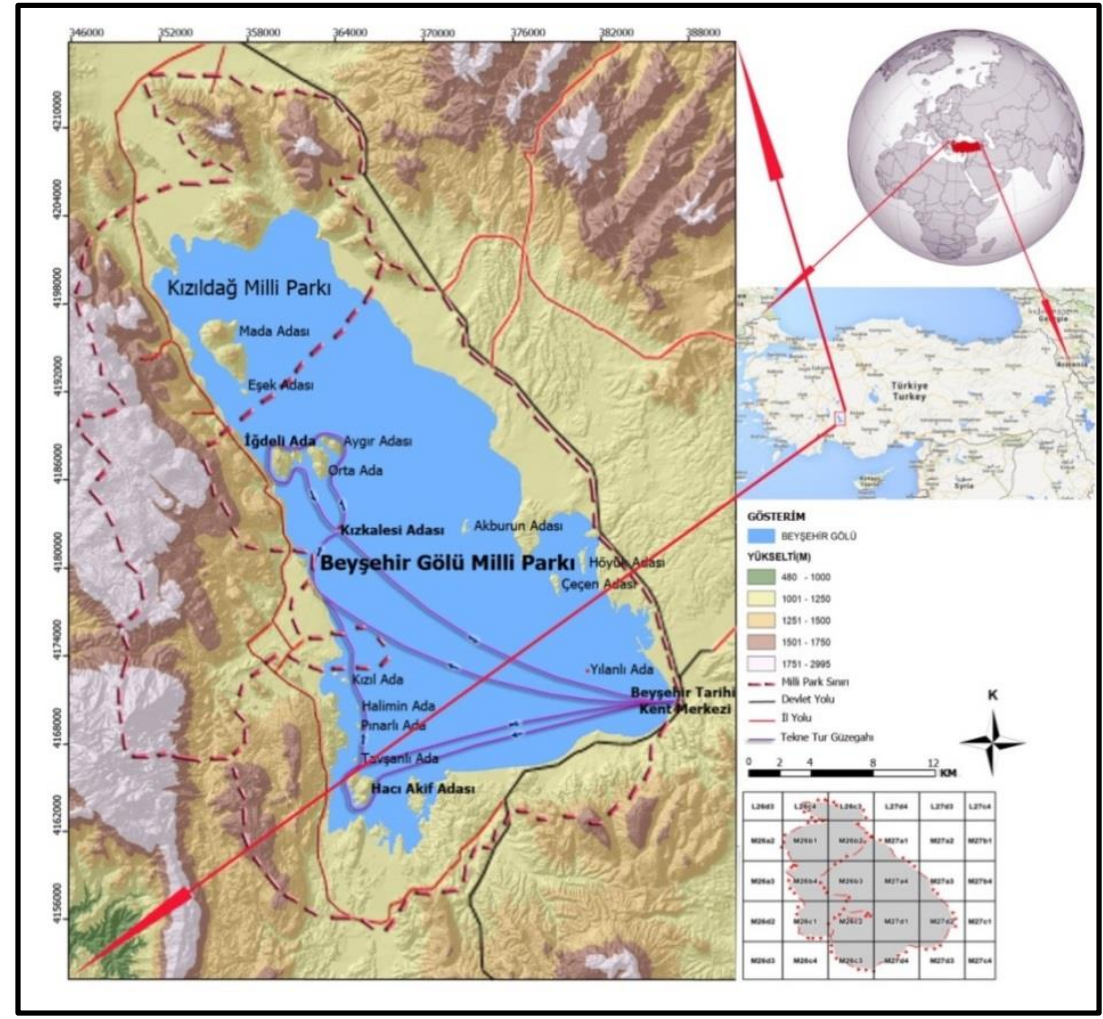

Şekil 1. Beyşehir Gölü Milli Parkı coğrafi konum haritası (Anonim 2013)

Beyşehir Gölü, 1991 yılında 1. Derece Doğal Sit ilan edilmiştir. Yüz ölçümü bakımından Türkiye'nin üçüncü büyük gölü olup tatlı su gölleri arasında ise en büyük olanıdır. Deniz seviyesinden 1.116 m yükseklikte olan gölün derinliği en fazla 10 m'dir. Türkiye'deki önemli kuş alanlarından birisi olarak kabul edilen alanda 153 kuş türü olup göldeki irili ufaklı adalar ve sazlıklar pelikan, balıkçıl, karabatak ve martı gibi su kuşlarının kışlama ve kuluçka alanlarıdır. Bu nedenle göl doğal yaşamın devamlılığını sağlayan önemli bir ekolojik ortamdır. Beyşehir Gölü'nde 6 farklı familyaya mensup 9 tür ve 2 alttür balık yayılış göstermektedir. (Anonim, 2001; Anonim, 2013). Beyşehir Gölü üzerinde kuşlar için üreme, beslenme, yumurtlama ve güvenle kuluçka yapmasına olanak sağlayan, hepsi ayrı doğal ve arkeolojik değerlere sahip, ortalama olarak 33 adet irili ufaklı ada vardır. (Anonim, 2001; Anonim, 2013).

Beyşehir Gölü Milli Parkı'ndaki tüm rekreasyonel alanların giriş kapısı bulunmadığından dolayı ziyaretçi sayısı kesin olarak bilinmemekle birlikte yılda yaklaşık 60.000 ziyaretçinin parkı ziyaret ettiği tahmin edilmektedir. Ziyareti süresince yapılan başlıca aktiviteler ise; yürüyüş, fotoğraf çekme ve tarihi kültürel alanları ziyarettir. $1 \mathrm{~km}$ uzunluğunda kumsala sahip olan göl yüzme ve güneşlenme, kuş gözlemciliği, sportif olta balıkçılı̆̆ (Anonim, 2013).

Ayrıca Milli Park'ta ziyaretçilere yönelik olarak 5 adet tekne tarafindan turlar düzenlenmektedir. Tura çıkan tekneler 3 farklı rotadan birini takip etmektedir. $\mathrm{Bu}$ rotalar; "Beyşehir-Hacı Akif Adası-Beyşehir", "Beyşehir-Hacı Akif Adası-Kızkalesi-Beyşehir" ve "Beyşehir-Kızkalesi-İğdeli Ada-Beyşehir" dir. İğdeli Ada'da tekneler yüzme molası vermekte olup, Kızkalesi ve Hacı Akif Adası'nda ise yürüyüş molası vermektedirler. Üç Adalar olarak bilinen İğdeli Ada, Orta Ada ve Aygır Ada ile birlikte eşsiz güzellikte bir boğaz oluşturmaktadır. Kıyıları genellikle dik ve derin olan İğdeli Ada'nın kumsalı kızıl kumlarla kaplıdır. Hacı Akif Adası, adalar kümesinin güneyindedir. Adada, Sarkıt ve dikitleriyle ünlü $100 \mathrm{~m}$ uzunluğunda duvarları tarihi duvar süsleri ile bir mağara ile Roma dönemine ait tapınak kalıntıları yer almaktadır. Adalar kümesinin doğu kısmında yer alan ve pek çok tarihi kalıntının bulunduğu Kızkulesi Adası ise bir kuş cenneti olarak tanımlanmaktadır. 5 dekarlık bir ada olup en yüksek noktası 1138 metredir. Kubadabat Sarayı'nın 3,5 km kadar kuzeydoğusunda bulunan ada Sarayın harem dairesi olarak kullanılmıştır. Kayalık özelliği de taşıyan ada içinde birçok eski yapı kalıntısı vardır (Anonim, 2001; Anonim, 2013). 


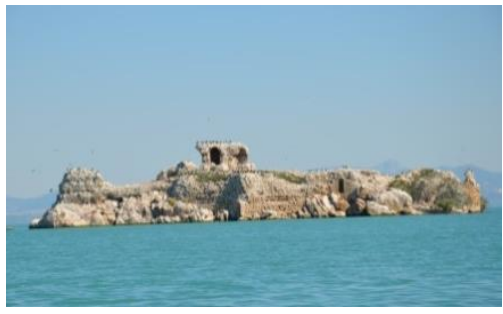

Kız Kalesi

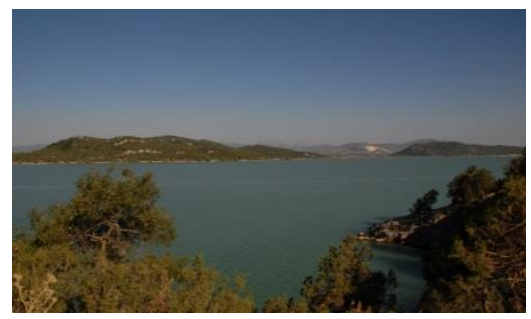

Hacı Akif Adası

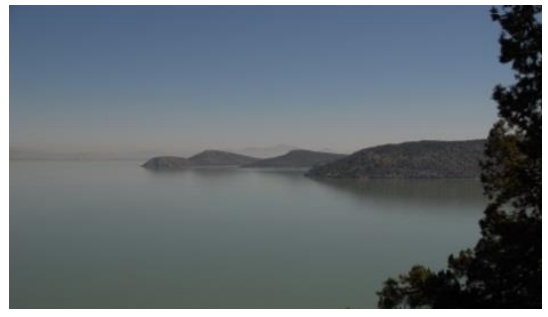

İ̆gdeli Ada

Şekil 2. Tekne turları kapsamında ziyaret edilen adalar (Anonim, 2013)

Yöntem: Çalışmada aşağıdaki süreç takip edilmiştir.

1. Literatürlerin Derlenmesi: Beyşehir Gölü Milli Parkı'na ve Beyşehir Gölü'ne ilişkin literatürlerden ve Milli Park Müdürlügü arşivinden yararlanarak çalışma alanının coğrafik ve biyolojik özellikleri, kurumsal ve yasal statüsü, yıllık ziyaretçi sayısı ve ziyaretçi profili ile ilgili bilgiler, Beyşehir Meteoroloji İstasyonuna ilişkin 41 yıllık (1972-2012) meteorolojik veriler temin edilmiştir.

2. Arazi Çalışmaları: Gerçekleştirilen arazi çalışmalarında, tur teknelerinin rotaları, GPS ile koordinatları belirlenerek haritalandırılmış, teknelerin rota uzunlukları ve tur süreleri hesaplanmıştır. Tekneler için adalar etrafinda konaklamaya uygun alan büyüklüğü, fiziksel olarak adaların kıyı şeridi uzunluğu, batimetrik yapısı adaların coğrafik özellikleri saptanarak belirlenmiştir. Mola verilen adalardaki yürüyüş parkurları ve plajlar, GPS ile koordinatları belirlenerek haritalandırılmış, parkur uzunlukları ve plaj alanı büyüklükleri saptanmış, her 20 metrede bir parkurların rakımı altimetre ile ölçülerek parkurların ortalama ve maksimum eğimleri ölçülmüştür.

3. Kapasite Analizleri: Beyşehir Gölü Milli Parkı'nda, Beyşehir Gölü tekne turlarının rekreasyonel taşıma kapasitesinin belirlenmesine yönelik olarak "Korunan Alanlarda Taşıma Kapasitesi Tahmin Yöntemi”" (Ceballos ve Lascurain, 1996) ile Yıldırım ve Tuğrul-İçemer (2010)'in LAC (Limits of Acceptable Change - Kabul Edilebilir Değişim Sınırları) modelini kullanarak geliștirdikleri "Tekneler İçin Kullanım Alanı Kabul Edilebilirlik Standartları"ndan faydalanılarak bütünleşik bir yöntem oluşturulmuştur.

"Korunan Alanlarda Taşıma Kapasitesi Tahmin Yöntemi" (Ceballos- Lascurain 1996): Bu yönteme göre büyüklüğü belirli olan bir rekreasyon alanına, belirli bir zaman aralığında rekreasyonel faaliyetin çeşidine göre "fiziksel” olarak sığabilecek ziyaretçi sayısı da belirlidir. Ancak, rekreasyon alanlarında çeşitli fiziksel, ekolojik veya iklimsel faktörler ziyaretleri kısıtlamaktadır. $\mathrm{Bu}$ faktörlerden dolayı "gerçekte" alanın ziyaretçi kapasitesi düşmektedir. Ayrıca eleman yetersizliği, hizmet tesislerindeki yetersizlik veya güvenlik yetersizliği gibi yönetim kaynaklı problemler ise alandaki tüm ziyaretçilere "etkin" bir hizmetin verilmesini kısıtlamaktadır. $\mathrm{Bu}$ durumda da alanın ziyaretçi kapasitesi düşmektedir. $\mathrm{Bu}$ mantık çerçevesinde yöntemde üç rekreasyonel taşıma kapasitesi düzeyi tanımlanmaktadır. Bunlar;

Fiziksel Taşıma Kapasitesi $(F T K)$, aşağıdaki formülle hesaplanmaktadır:
$F T K=A \times Z / a \times R f \quad$ Bu formülde

FTK: Fiziksel Taşıma Kapasitesi

A: Alan (Ziyaretçilerin kullanımı için mevcut alan veya patika)

Z/a: Ziyaretçi/alan (Ziyaretçi başına düşen alan veya patika uzunluğu)

$\boldsymbol{R f}$ : Rotasyon faktörü

$\boldsymbol{R f}=\boldsymbol{g s} / \boldsymbol{z s} \quad$ Bu formülde;

$g s$ :Bir alanın günlük açık olduğu süre

$z s$ : Bir ziyaretin ortalama süresi

Gerçek Tașıma Kapasitesi (GTK), aşağıdaki formül ile hesaplanmaktadır.

$G T K=F T K-F d_{1^{-}} F d_{2}-$ $-F d_{n}$

$\mathrm{Bu}$ formülde;

GTK: Gerçek Taşıma Kapasitesi

FTK: Fiziksel Taşıma Kapasitesi

$\boldsymbol{F d}$ : Her bir faktör için hesaplanan düzeltme değeri olup aşağıdaki formülle hesaplanır:

$F d=F s / F t x 100$ $\mathrm{Bu}$ formülde;

Fd: Faktörün düzeltme değeri

Fs: Faktörün sınırlayıcı değeri

Ft: Faktörün toplam değeri

Etkin Taşıma Kapasitesi (ETK): aşağıdaki formül ile hesaplanmaktadir.

$\boldsymbol{E T K}=\boldsymbol{G T K} \boldsymbol{x} \boldsymbol{Y K} \quad$ Bu formülde;

ETK: Etkin Taşıma Kapasitesi

GTK: Gerçek Taşıma Kapasitesi

YK: Yönetim Kapasitesi

Formülde YK'nın en büyük değeri 1'e eșit olup, YK yönetimce sağlanan mevcut koşulların toplamını ifade etmektedir. $\mathrm{Bu}$ koşullar, altyapı, üstyapı ve tesisler, yönetim kadrosu, eleman sayısı, eleman niteliği, fonlar, mevzuat vb. birçok değişkenden oluşmaktadır. Bu sebeplerle yönetim kapasitesinin tahmin edilmesi oldukça güçtür. Bu çalışmada ETK hesaplarında "YK" aşağıdaki formül ile belirlenmiştir:

$\boldsymbol{Y K}=$ Mevcut Personel Sayıs1/ Olması Gereken Asgari Personel Sayısı 
"Tekneler İçin Kullanım Alanı Kabul Edilebilirlik Standartları" (Yıldırım ve Turulİcemer, 2010): Tekne yolcu kapasiteleri; teknelerin boyu, eni, kat sayısı ve iç dizayna (koltuk konumları, koltuklar arası mesafe) göre değişmekle birlikte Yıldırım ve Tuğrul-İçemer (2010) Kabul Edilebilir Değişiklik Sınırları Modeli (LAC) ile Phaselis Koyu'nun fiziksel taşıma kapasitesinin belirlenmesini konu alan çalışmalarında boyutlarına göre tur teknelerinin ortalama yolcu kapasitelerini belirtmişlerdir (Çizelge 1). Çalışmalarında, boyutlarına göre tekneler için kullanım alanı kabul edilebilirlik standartları ise Çizelge 2'de sunulmuş olup, iki tekne arasındaki mesafenin manevra yaparken kaza riskini azaltmak amacı ile $80 \mathrm{~m}$ olması uygun görülmüştür.

Çizelge 1. Tekne ölçüleri ve tekne kullanıcı sayıları

\begin{tabular}{|c|c|c|c|}
\hline \multicolumn{2}{|c|}{ Tekne Ölçüleri } & \multirow{2}{*}{ Tekne Alanı $\left.\mathbf{( m}^{\mathbf{2}}\right)$} & \multirow{2}{*}{ Tekne Kullanıcı Sayısı } \\
\hline a (Tekne Boyu) & b (Tekne Eni) & 30 & 8 \\
\hline 10 & 3 & 90 & 20 \\
\hline 18 & 5 & 100 & 25 \\
\hline 20 & 5 & 125 & 65 \\
\hline 25 & 5 & & \\
\hline
\end{tabular}

Çizelge 2. Tekneler için kullanım alanı kabul edilebilirlik standartları

\begin{tabular}{|c|c|c|}
\hline Standart Mesafe (m) & Durum & Kabul edilebilirlik \\
\hline 120 & Çok Geniş & Evet \\
\hline 100 & Geniş & Evet \\
\hline $\mathbf{8 0}$ & Uygun & Evet \\
\hline 60 & Az Dar & Evet \\
\hline 30 & Dar & Hayır \\
\hline 20 & Çok Dar & Hayır \\
\hline 10 & Aşır Dar & Hayır \\
\hline
\end{tabular}

Tekne turlarının rekreasyonel taşıma kapasitesinin belirlenebilmesi yönünde öncelikli olarak turların gezi veya yüzme amaçlı mola verdikleri adaların "Anlık" Taşıma Kapasitelerinin belirlenmesi gerektiği düşünülmüştür. Sonrasında ise adaların ve tekne turlarının "Fiziksel", "Gerçek" ve "Etkin" Taşıma Kapasiteleri, Korunan Alanlarda Taşıma Kapasitesi Tahmin Yöntemi (Ceballos ve Lascurain, 1996)'ne göre hesaplanmıştır.

4. Analizlerin değerlendirilmesi ve önerilerin geliştirilmesi: Elde edilen, matematiksel değerler yorumlanarak konuya ilişkin öneriler getirilmiştir.

\section{BULGULAR}

Anlık Kapasite ve Fiziksel Taşıma Kapasitesi (FTK) Hesapları: Mola verilen adalardaki rekreasyon alanlarının ziyaretçi kapasiteleri ile adaların çevresindeki göl alanlarının tekne kapasitelerinin eşleştirilmesi gerekmektedir. $\mathrm{Bu}$ eşleştirme ancak "Anlık Kapasite Değerleri” üzerinden yapılabilmektedir. $\mathrm{Bu}$ sebeple FTK hesaplarında rotasyon faktörü ilk başta 1 olarak alınarak "Anlık Kapasite" hesaplanmıştır.

Tekne turları 3 farkl rotadan birini takip etmektedir. $\mathrm{Bu}$ rotalar; Rota 1: "Beyşehir-Hacı Akif AdasıBeyşehir", Rota 2: "Beyşehir-Hacı Akif AdasıKızkalesi-Beyşehir" Rota 3: "Beyşehir-Kızkalesiİğdeli Ada-Beyşehir" dir. Bu 3 rotadan herhangi birini takip eden teknelerin her biri aynı saatte Beyşehir'den Çizelge 3. Adaların anlık taşıma kapasitesi ile ilgili özelliklerı ayrılıp, Beyşehir'e dönmektedir. İğdeli Ada'da tekneler yüzme molası vermekte, Kızkalesi ve Hac1 Akif Adası'nda ise gezi amaçlı yürüyüşler gerçekleştirilmektedir.

İğdeli Ada'da yüzmek ve güneşlenmek için adanın kuzey ve güneyinde bulunan 2 farklı koy kullanılmaktadır. Adanın güneyindeki koyun kuru plaj alanı $6780 \mathrm{~m}^{2}$, kuzeyindeki koyun ise kuru plaj alanı $1800 \mathrm{~m}^{2}$ olarak ölçülmüştür. Kızkalesi'nde gezi amaçlı kullanılan patikanın toplam uzunluğu 157 metre, Hacı Akif Adası'nda bulunan patika uzunluğu ise 1000 metre olarak ölçülmüştür. Mesire Yerleri Teknik İzahnamesi (2006)'nden faydalanılarak İğdeli Ada'da kişi başına düşen optimum kuru plaj alanı $10 \mathrm{~m}^{2}$ olarak hesaplara dahil edilmiştir. Kızkalesi ve Hacı Akif Adası'ndaki patikalarda 1 kişinin kapladığı doğrusal uzunluk $1 \mathrm{~m}$ olup her bir grup arasında olması gereken doğrusal uzunluk ise 50 m'dir (Ceballos ve Lacsurain, 1996). Patika hesaplarında maksimum grup büyüklüğü 50 ziyaretçi olarak alınmıştır. Bunun nedeni, 25 metre boyunda bir tekne yaklaşı olarak 65 ziyaretçi kapasitelidir (Yıldırım ve Tuğrul-İçemer, 2010). Gözlemler neticesinde ziyaretçilerin yaklaşık \%80'inin mola sırasında adaları gezmek istediği düşünülmektedir. $\mathrm{Bu}$ verilere göre İğdeli Ada'da aynı anda 858 ziyaretçinin plaj alanını kullanabileceği, Kızkalesi yürüyüş patikasını 100 ziyaretçinin ve Hacı Akif Adası yürüyüş patikasını ise 500 ziyaretçinin kullanabileceği hesaplanmıştır (Çizelge 3). 


\begin{tabular}{|c|c|c|c|}
\hline & İğdeli Ada & Kızkalesi & Hacı Akif Adası \\
\hline U: Patika uzunluğu (m) & & 157 & 1000 \\
\hline $\begin{array}{l}\text { Z/u: Patikalarda } 1 \text { kişinin kapladığı doğrusal } \\
\text { uzunluk(m) }\end{array}$ & & \multicolumn{2}{|c|}{1 (Ceballos-Lascurain 1996) } \\
\hline $\mathrm{G}_{\mathrm{u}}:$ Gruplar arasındaki minimum uzaklık (m) & & \multicolumn{2}{|r|}{50} \\
\hline $\mathrm{G}_{\mathrm{b}:}$ Maksimum ziyaretçi grubu büyüklüğü & & \multicolumn{2}{|c|}{ 50(Ceballos-Lascurain1996) } \\
\hline A: Kuru Plaj Alanı $\left(\mathrm{m}^{2}\right)$ & $6780+1800=8580$ & & \\
\hline Z/a: Kişi Başı Optimum Kuru Plaj Alanı $\left(\mathrm{m}^{2}\right)$ & 10 (Anonim, 2006) & & \\
\hline Rf: Rotasyon faktörü & \multicolumn{3}{|l|}{ - } \\
\hline Anlık Kapasite & 858 & 100 & $\mathbf{5 0 0}$ \\
\hline
\end{tabular}

Göl alanlarının anlı tekne kapasitelerini hesaplamada ise Çizelge 1'de sunulan "Tekne Ölçüleri ve Tekne Kullanıcı Sayıları" ile Çizelge 2'de sunulan "Tekneler için kullanım alanı kabul edilebilirlik standartları" dikkate alınmıştır. Bu standartlara göre; 25 metre boyunda 65 ziyaretçi kapasiteli teknenin kullanım alanı $8925 \mathrm{~m}^{2}, 20$ metre boyunda 25 ziyaretçi kapasiteli tekne kullanım alanı $8500 \mathrm{~m}^{2}, 18$ metre boyunda 20 ziyaretçi kapasiteli teknenin kullanım alanı $8330 \mathrm{~m}^{2}, 10$ metre boyunda 8 ziyaretçi kapasiteli teknenin kullanım alanı ise $7470 \mathrm{~m}^{2}$ 'dir. Adaların çevresindeki göl alanlarının batimetrik yapısı, adaların kıyı şeridi uzunluğu ve coğrafik özellikleri incelenerek konaklamalar için uygun olan göl alanı büyüklüğü saptanmıştır.
Kızkalesi Adası: Kızkalesi Adasının çevresinin kıyıdan ortalama 35 metre uzaklıktan itibaren 430 metrelik alanın konaklamalar için uygun olduğu saptanmıştır. İki tekne arasındaki mesafe 80 metre olarak alındığında ada etrafında aynı anda en fazla 5 adet tekne konaklayabilmektedir. Bu tekneler 10 metre, 18 metre boyunda tekneler olabileceği gibi 20 metre ve 25 metre boyunda 65 kişi kapasiteli teknelerde olabilir. Ancak Kızkalesi Adası'nı aynı anda 25 metre veya 20 metre boyunda 5 adet teknenin ziyaret etmesi durumunda 5 teknedeki toplam ziyaretçi sayısı Kızkalesi Adası'nın anlık ziyaretçi kapasitesinden yüksek olacaktır. Anlık ziyaretçi kapasitesini aşmayan tekne boyutlarına göre tekne sayıları seçenekler halinde Çizelge 4'te sunulmuştur.

Çizelge 4. Büyüklüklerine göre Kızkalesi çevresine yanaşabilecek maksimum tekne sayısı

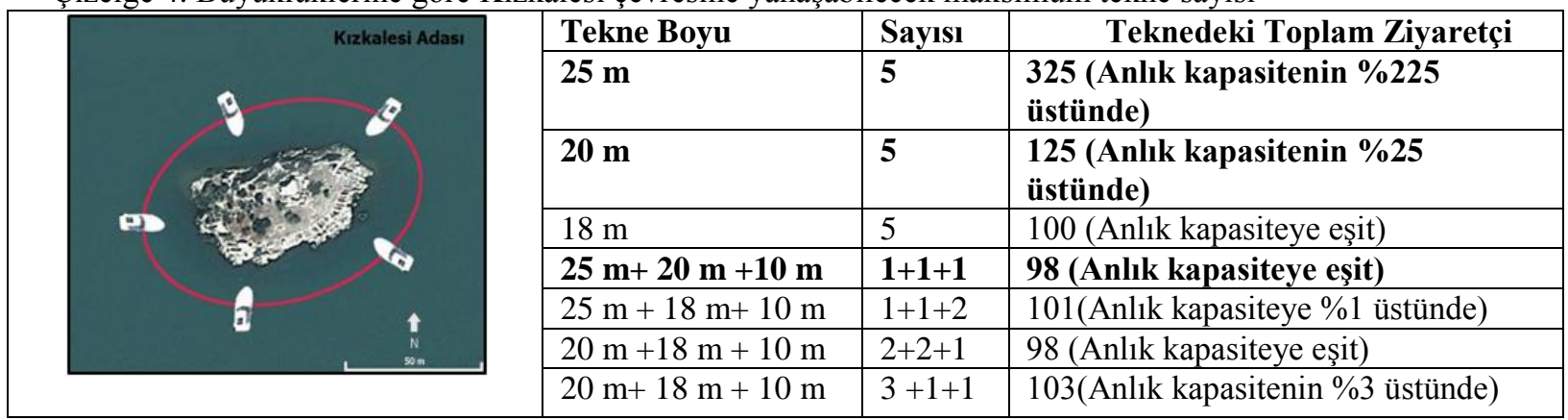

Hacı Akif Adası: $80.000 \mathrm{~m}^{2}$ 'lik bir alanın tekneler açısından konaklama için uygun olduğu saptanmıştır. Hacı Akif Adasını Rota 1 ve Rota 2'yi takip eden tekneler ziyaret etmektedir. Rota 2, Kizkalesi'nde mola vermekte olup yolcu kapasitesi 100’dür. Bununla birlikte
Rota 1 ve Rota 2'yi takip eden tekneler aynı saatlerde Hacı Akif Adası'nda olacaktır. Bu sebeple Hacı Akif Adası çevresinin anlık tekne kapasite seçenekleri belirlenirken Kızkalesi çevresinin anlık tekne kapasite seçenekleri dikkate alınmıştır (Çizelge 5).

Çizelge 5. Büyüklüklerine göre Hacı Akif Adası'na yanaşabilecek maksimum tekne sayısı

\begin{tabular}{|c|c|c|c|}
\hline \multirow{7}{*}{ 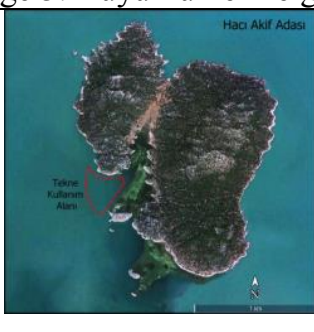 } & Tekne Boyu & Sayısı & Teknedeki Toplam Ziyaretçi \\
\hline & $25 \mathrm{~m}$ & 9 & $\begin{array}{l}585 \text { (Anlık kapasitenin \%17 } \\
\text { üstünde) }\end{array}$ \\
\hline & $25 m+18 m$ & $4+5$ & 360 (Anlık kapasitenin altında) \\
\hline & $25 m+20 m+10 m$ & $7+1+1$ & 488 (Anlık kapasitenin altında) \\
\hline & $25 m+18 m+10 m$ & $6+1+2$ & 426 (Anlık kapasitenin altında) \\
\hline & $25 m+20 m+18 m+10 m$ & $4+2+2+1$ & 358 (Anlık kapasitenin altında) \\
\hline & $25 m+20 m+18 m+10 m$ & $4+3+1+1$ & 363 (Anlık kapasitenin altında) \\
\hline
\end{tabular}


İğdeli Ada: Konaklamaya uygun alanın büyüklüğì $140.000 \mathrm{~m}^{2}$ 'dir. İğdeli Ada'yı Rota 3'ü takip eden tekneler ziyaret etmektedir. Rota 3'ü takip eden tekneler ayrıca Kızkalesi Adası'nı da ziyaret etmektedir. Rota 2'yi takip eden tekneler de Kızkalesi Adası'nı ziyaret etmektedir. Ancak ziyaret saatleri birbirinden farklı olup, aynı saatlerde ada çevresinde bulunmamaktadırlar.
İğdeli Ada çevresinin anlık tekne kapasiteleri hesaplanırken alternatif bir rota olarak "Beyşehir- İğdeli Ada-Beyşsehir" düşünülmüştür. $\mathrm{Bu}$ sebeple İğdeli Ada'nın çevresinin anlık tekne kapasite seçenekleri belirlenirken Kızkalesi çevresinin anlık tekne kapasite seçenekleri dikkate alınmıştır.

Çizelge 6. Büyüklüklerine göre İğdeli Ada'ya yanaşabilecek maksimum tekne sayısı

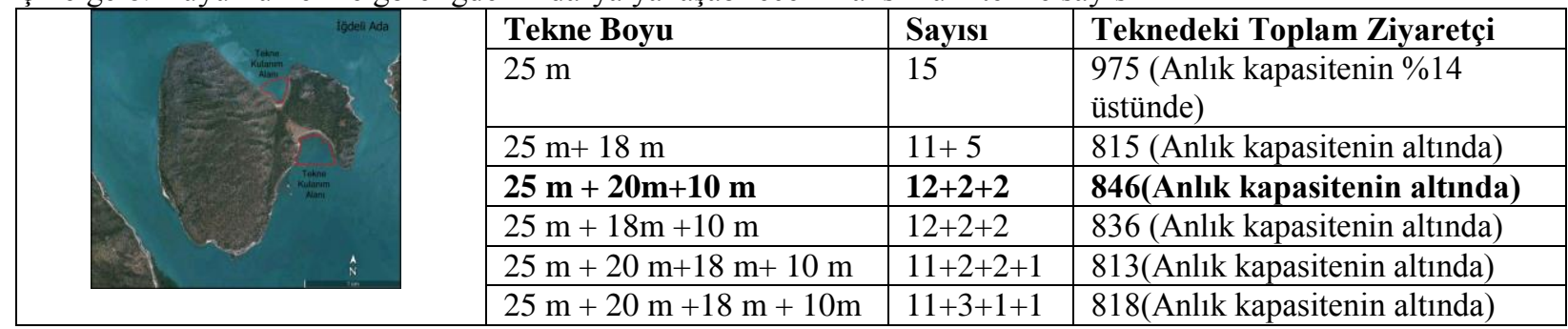

Hacı Akif Adası ve İğdeli Ada için hesaplanan seçenekler arasında teknedeki toplam ziyaretçi sayılarının en fazla olduğu seçenek dikkate alınarak her bir rotayı takip ederek tura çıkabilecek maksimum ziyaretçi taşıyan tekne sayısı hesaplanmıştır. Ayrıca alternatif bir rota (Beyşehir- İğdeli Ada- Beyşehir) önerilerek bu rotayı takip edebilecek maksimum ziyaretçi taşıyan tekne sayısı da hesaplanmıştır (Çizelge 7). Bununla birlikte adaların ziyaretçi kapasitesini aşmayan diğer seçenekler de hesaplanarak Çizelge 8'de sunulmuştur.

Çizelge 7. Her bir rotayı takip edebilecek maksimum tekne sayısı

\begin{tabular}{|c|c|c|c|c|c|c|}
\hline \multicolumn{4}{|c|}{ Rotalar } & Tekne Boyları & Tekne & Tekne \\
\hline Beyşehir & \multicolumn{2}{|c|}{ Hacı Akif Adası } & Beyşehir & $25 \mathrm{~m}+20 \mathrm{~m}+10 \mathrm{~m}$ & $6+0+0$ & 390 \\
\hline Beyşehir & $\begin{array}{c}\text { Hacı Akif } \\
\text { Adası }\end{array}$ & Kizkalesi & Beyşehir & $25 \mathrm{~m}+20 \mathrm{~m}+10 \mathrm{~m}$ & $1+1+1$ & 98 \\
\hline Beyşehir & K1zkalesi & İğdeli Ada & Beyşehir & $25 \mathrm{~m}+20 \mathrm{~m}+10 \mathrm{~m}$ & $1+1+1$ & 98 \\
\hline Beyşehir & \multicolumn{2}{|c|}{ İğdeli Ada } & Beyşehir & $25 \mathrm{~m}+20 \mathrm{~m}+10 \mathrm{~m}$ & $11+1+1$ & 748 \\
\hline \multicolumn{3}{|c|}{$\begin{array}{c}\text { Adaların Anlık Ziyaretçi } \\
\text { Kapasiteleri }\end{array}$} & \multicolumn{4}{|c|}{ Adaların Anlık Maksimum Tekne Kapasiteleri } \\
\hline \multicolumn{2}{|c|}{ K1zkalesi } & 100 & K1zkalesi & $25 \mathrm{~m}+20 \mathrm{~m}+10 \mathrm{~m}$ & $1+1+1$ & 98 \\
\hline \multicolumn{2}{|c|}{ Hacı Akif Adası } & 500 & $\begin{array}{c}\text { Hacı Akif } \\
\text { Adası }\end{array}$ & $25 \mathrm{~m}+20 \mathrm{~m}+10 \mathrm{~m}$ & $7+1+1$ & 488 \\
\hline \multicolumn{2}{|c|}{ İğdeli Ada } & 858 & İğdeli Ada & $25 \mathrm{~m}+20 \mathrm{~m} 10 \mathrm{~m}$ & $12+2+2$ & 846 \\
\hline
\end{tabular}

Çizelge 8. Beyşehir Gölü Milli Parkı'nda tura çıkabilecek tekne sayıları

\begin{tabular}{|c|c|c|}
\hline Tekne Boyları & Tekne Sayıları & Teknelerdeki Toplam Ziyaretçi Sayısı \\
\hline $25 \mathrm{~m}+20 \mathrm{~m}+10 \mathrm{~m}$ & $19+3+3$ & $\mathbf{1 3 3 4}$ (en fazla ziyaretçi) \\
\hline $25 \mathrm{~m}+18 \mathrm{~m}+10 \mathrm{~m}$ & $18+3+4$ & 1262 \\
\hline $25 \mathrm{~m}+20 \mathrm{~m}+18 \mathrm{~m}+10 \mathrm{~m}$ & $15+6+2+2$ & 1181 \\
\hline $25 \mathrm{~m}+18 \mathrm{~m}$ & $15+10$ & 1175 \\
\hline $25 \mathrm{~m}+20 \mathrm{~m}+18 \mathrm{~m}+10 \mathrm{~m}$ & $15+4+4+2$ & 1171 \\
\hline
\end{tabular}

Adaların FTK'sının hesaplanabilmesi için anlık kapasitenin Rf ile çarpılması gerekmektedir. Teknelerin aynı saatlerde tura başladığı ve rotanın uzunluğu dikkate alındığında her tekne sadece gün içerisinde sadece 1 kere tura çıkabilmektedir. Bununla birlikte Hacı Akif Adası ve İğdeli Ada'da 2 farklı rotayı takip eden tekneler mola vermektedir. Ancak güzergâhlar incelendiğinde teknelerin aynı saatler aralığında adalarda mola verdikleri anlaşılmaktadır. Bu sebeple Hacı Akif Adası ve İğdeli Ada'nın Rf'si 1 olup anlık kapasite değerleri FTK'ya eşittir. Kızkalesi Adası'nda da 2 farklı rotayı takip eden tekneler mola vermektedir. Ancak tekneler farklı saatlerde adada mola vermekte olup mola süreleri, ada üzerindeki gezinti yolunun kısa olmas1 sebebi ile mola saati kisadir. $\mathrm{Bu}$ sebeple Kızkalesi Adası'nın Rf'si 2'dir (Çizelge 9). 
Çizelge 9. Tekne turlarının FTK değerleri

\begin{tabular}{|c|c|c|c|}
\hline \multicolumn{2}{|c|}{ Formül: FTK $=A \times$ Z/ $a \times$ Rf } & Hacı Akif Adası \\
\hline & İğdeli Ada & Kıkalesi & 500 \\
\hline $\begin{array}{c}\text { FTK: } \\
\text { ziyaretçi/gün) }\end{array}$ & 858 & 200 & Toplam Tekne \\
\hline & Tekne Boyları & Tekne Sayıları & 25 \\
\hline FTK : (tekne/gün) & $25 \mathrm{~m}+20 \mathrm{~m}+10 \mathrm{~m}$ & $19+3+3$ & \\
\hline
\end{tabular}

Gerçek Taşıma Kapasitesi (GTK) Hesapları: Tekne turlarının GTK'sının hesaplanabilmesi için öncelikle ziyareti engelleyen faktörlerin tanımlanması ve faktörlerin düzeltme değerlerinin hesaplanması gerekmektedir. Adaların ziyaretini engelleyen veya kısıtlayan faktörlerin sıcaklık, yağış, ortalama kapalı gün sayısı, kuvvetli rüzgârlı gün sayısı ve kuşların üreme dönemleri olduğu düşünülmüştür. Bununla birlikte su kirliliği kontrolü yönetmeliğine göre göl ve göletlere, arıtılmamış evsel ve endüstriyel nitelikli atık sular verilememektedir. $\mathrm{Bu}$ sebeple tur tekneleri, katı atıklarını ilgili belediyeye ve pis suları ise kıyıda kurulması gereken atı su toplama sistemlerine aktarmakla yükümlü olup bu sebeple yönteme dahil edilmemiştir.

Rekreasyonel faaliyetleri zorlaştıran iklimsel düzeltme faktörlerinin hesaplanmasında Beyşehir Meteoroloji İstasyonuna ilişkin 41 yıllık (1972-2012) meteorolojik verileri kullanılmıştır (Çizelge 10).

Sicaklık Düzeltme Faktörü $\left(\mathrm{F}_{\mathrm{ds}}\right)$ :. Sicaklığın $\geq 25^{\circ} \mathrm{C}$ ve göl suyu sıcaklığının $\geq 18$ olduğu günler İğdeli Ada'da yüzme ve güneş banyosu için uygun olan günlerdir (Güçlü,2010). Hava sıcaklığının $10^{\circ} \mathrm{C}-25^{\circ} \mathrm{C}$ arasında olduğu günler Kızkalesi ve Hacıakif Adası'nda yürüyüş için uygun olan günlerdir (Li ve Lin,2012).
Yağ1ș Düzeltme Faktörü $\left(\mathrm{F}_{\mathrm{dy}}\right)$ : Yağış genel olarak rekreasyonel faaliyetleri kısıtlayan bir faktör olup, fotoğraf ve video çekimlerini, engellemekte, güneşlenmeyi ve göle girmeyi etkilemekte, yürüyüş yollarında zemini kayganlaştırarak aktiviteyi zorlaştırmakta ve riskli hale getirmektedir. Bu sebeple yağışın $\geq 0.1 \mathrm{~mm}$ olduğu y1llık ortalama gün sayısı ziyareti kısıtlayan bir faktör olarak değerlendirilmiştir.

Kapalı Hava Düzeltme Faktörü $\left(\mathrm{F}_{\mathrm{d} k}\right)$ : Kapalı havalar, deniz ve güneş banyosu aktivitesi için olumsuz bir etken olarak görülerek kapalı günler ziyareti kısıtlayan bir faktör olarak değerlendirilmiştir.

Kuvvetli Rüzgarlı ve Üstü Düzeltme Fatörü $\left(\mathrm{F}_{\mathrm{dr}}\right)$ : Bofor Rüzgar Skalasına göre Kuvvetli Rüzgar (10.8$13.8 \mathrm{~m} / \mathrm{sn}$ ) ve üstündeki kuvvette esen rüzgarlı günler tekne turları için engel teşkil eden sertlikte rüzgarlardır.

Yaban Hayatı Kısıtlama Faktörü $\left(\mathrm{F}_{\mathrm{dü}}\right)$ : Adalar, farklı türlerdeki su kuşlarının üreme alanıdır. 1 Mayıs- 30 Haziran tarihleri su kuşlarının üremesi bakımından önemli tarihler olup bu tarihlerin rekreasyon için uygun olmayan dönemler olduğu düşünülmüştür.

Adaların GTK ile ilgili özellikleri kullanılarak Çizelge 11'deki düzeltme faktörleri hesaplanmıştır.

Çizelge 10. Tekne turlarının GTK ile ilgili özellikleri

\begin{tabular}{|l|c|c|}
\hline & Kizkalesi ve Hacı Akif Adası & İgdeli Ada \\
\hline $\begin{array}{l}\text { S: Sıcaklı̆̆ın tanımlanan rekreasyonel faaliyete uygun } \\
\text { olduğu gün sayısı }\end{array}$ & 165 & 96,2 \\
\hline Y:Yağışın $\geq 0.1 \mathrm{~mm}$ olduğu yıllık ort. gün sayısı & 46,7 & 21,1 \\
\hline YS: Ort. yağış süresi (saat) & 2 & 2 \\
\hline K:Ort. kapalı gün sayısı & - & 4.8 \\
\hline R:Kuvvetli rüzgarlı gün sayısı & 25 & 13 \\
\hline TS1: Ortalama tekne turu süresi (saat) & 9 & 9 \\
\hline Ü: Kuşların kuluçka dönemleri & 61 & 29,9 \\
\hline
\end{tabular}

G, Y, K, R: Yıl içerisindeki sıcaklığın tanımlanan rekreasyonel faaliyete uygun olduğu dönem aralığı için hesaplanmıştır.

Çizelge 11. Tekne turlarının $\mathrm{F}_{\mathrm{d}}$ (Faktör Düzeltme) değeri

\begin{tabular}{|l|c|c|}
\hline \multicolumn{1}{|c|}{ Formül: $\mathrm{F}_{\mathrm{d}=} \mathrm{F}_{\mathrm{s}} / \mathrm{F}_{\mathrm{t}} \times 100$} & Kıkkalesi ve Hacı Akif Adası & İğdeli Ada \\
\hline Rahatsı Eden Sicaklık Faktörü $\left(\mathrm{F}_{\mathrm{ds}}\right)$ & $\% 57,8$ & $\% 73,6$ \\
\hline Yağış Düzeltme Faktörü $\left(\mathrm{F}_{\mathrm{dy}}\right)$ & $\% 2,8$ & $\% 1,3$ \\
\hline Kapalı Hava Düzeltme Faktörü $\left(\mathrm{F}_{\mathrm{dk}}\right)$ & - & $\% 1,3$ \\
\hline Rüzgar Düzeltme Faktörü $\left(\mathrm{F}_{\mathrm{dr}}\right)$ & $\% 6,8$ & $\%, 6$ \\
\hline Yaban Hayatı Düzeltme Faktörü (Fdü) & $\% 16,7$ & $\%, 2$ \\
\hline
\end{tabular}


Rekreasyonu engelleyen veya kisitlayan incelendiğinde faktörlerin her gün değil, sadece yllın belirli dönemlerinde rekreasyonu kıstladıkları görülmektedir. $\mathrm{Bu}$ sebeple gerçek taşıma kapasitesinin ziyaretçi/yıl olarak yorumlanması daha doğrudur. Buna göre 1 yıl içerisinde İğdeli Ada 71.175, Kızkalesi
11.680, Hacı Akif Adası ise 58.035 defa ziyaret edilebilecektir. Rekreasyonu kistlayan faktörler ve adaların GTK değerlerine göre 25 tekne ile yıl içerisinde toplam 2.500 defa tekne turu yapılabileceği hesaplanmıştır.

Çizelge 12. Tekne turlarının GTK değerleri

\begin{tabular}{|c|c|c|c|}
\hline \multicolumn{4}{|c|}{ Formül: GTK $=$ FTK $\times\left(100-\mathrm{F}_{\mathrm{d} 1} / 100\right) \times\left(100-\mathrm{F}_{\mathrm{d} 2} / 100\right) \times \ldots . \mathrm{x}\left(100-\mathrm{F}_{\mathrm{dn}} / 100\right)$} \\
\hline & İğdeli Ada & Kızkalesi & Hacı Akif Adası \\
\hline GTK: (ziyaretçi/yıl) & 71.175 & 11.680 & 58.035 \\
\hline GTK : (tekne turu/yil) & \multicolumn{3}{|c|}{ (toplam 25 tekne ile yll içerisin } \\
\hline
\end{tabular}

Etkin Taşıma Kapasitesi (ETK) Hesapları: Milli Park'ta görev yapan mevcut personel sayısı ile Beyşehir Gölü Milli Parkı Şefi ile uzmanların yaptığı görüşmeler yolu ile tespit edilen ideal personel sayısı Çizelge 13'de verilmiştir. Buna göre Beyşehir Gölü Milli Parkı'nın yönetim kapasitesi (YK) 0,33 'dür.

Çizelge 13. Beyşehir Milli Parkı yapılanma şeması

\begin{tabular}{|c|c|c|c|}
\hline Mevcut Yapılanma (MY) & Sayı & İdeal Yapılanma (ï) & Sayı \\
\hline Milli Park Müdürü & 1 & Milli Park Müdürü & 1 \\
\hline Orman mühendisi & - & Orman mühendisi & 1 \\
\hline İdare Memuru & - & İdare Memuru & 2 \\
\hline Katip & - & Katip & 1 \\
\hline Orman Muhafaza Memuru & 1 & Orman Muhafaza Memuru & 1 \\
\hline Rehber (Devamlı) & 2 & Rehber (Devamlı) & 4 \\
\hline Rehber (Mevsimlik) & - & Rehber (Mevsimlik) & 1 \\
\hline Bakım Amiri & - & Bakım Amiri & 1 \\
\hline Şöför & 1 & Şöför & 2 \\
\hline İşçi & 1 & İşçi & 2 \\
\hline Toplam & - & Toplam & 2 \\
\hline & $\mathbf{6}$ & & $\mathbf{1 8}$ \\
\hline
\end{tabular}

Adaların Etkin Taşıma Kapasitesi (ETK), Yönetim Kapasitesi (YK) ile Gerçek Taşıma Kapasitesinin (GTK) çarpımına eşit olup, ETK değerleri Çizelge 14'te sunulmuștur. Gerçekleștirilen hesaplamalar sonucunda Milli Park'ın mevcut yönetim olanakları dâhilinde, yıl içerisinde İğdeli Ada'yı 23.360 kişi, Kızkalesi Adası'nı 4.014 kişi, Hacı Akif Adası'nı ise 18.980 kişi ziyaret edebileceği ve 8 tekne ile y1l içerisinde toplam 800 defa tur yapılabileceği saptanmıştır. Bununla birlikte YK yılın belirli günlerinde değil yılın her günü kapasiteyi etkilemektedir. Bu sebeple hesaplanan FTK değerleri de aslında YK oranında azalmaktadır. Bu bağlamda gün içerisinde tura çıkabilecek toplam tekne sayısı 8'e düşerken, gün içerisinde adaları ziyaret edebilecek toplam ziyaretçi sayısı da aynı oranda $(0,33)$ düşmektedir.

Çizelge 14. Adaların ETK değerleri

\begin{tabular}{|c|c|c|c|}
\hline Formül & \multicolumn{2}{|c|}{ ETK= GTK x YK } & $\mathrm{YK}=\mathrm{MY} / \mathrm{IY}$ \\
\hline & İğdeli Ada & Kızkalesi & Hacı Akif Adası \\
\hline ETK: (ziyaretçi/gün) & 283 & 66 & 165 \\
\hline ETK: (ziyaretçi/yıl) & 23.360 & 4.015 & 18.980 \\
\hline & Tekne Boyları & Tekne Sayıları & Toplam Tekne \\
\hline ETK: (tekne/ gün) & $25 m+20 m+10 m$ & $6+1+1$ & 8 \\
\hline ETK: (tekne turu/yıl) & \multicolumn{3}{|c|}{800 (toplam 8 tekne ile yıl içerisinde çıkılabilecek tekne turu sayısı) } \\
\hline
\end{tabular}

\section{TARTIŞMA ve SONUÇ}

Bu çalışmada, Beyşehir Gölü Milli Parkı'nın ve Beyșehir Gölü'nde gerçekleștirilen tekne turu faaliyetinin sürdürülebilirliği yönünde, doğru bir planlama ve yönetim yaklaşımı geliştirebilmek için rekreasyonel tekne taşıma kapasitesi analizleri ile tekne turları limitinin eşik değerinin belirlenmesi amaçlanmıştır.

Beyșehir Gölü'ndeki tekne turları kapsamında 3 farklı rekreasyonel aktivite olan tekne gezintisi, yüzme ve güneş banyosu ile yürüyüş faaliyeti gerçekleşmekte olup tüm kara, kıyı ve göl alanlarının taşıma kapasitesi 
bağlamında birbirleri ile etkileşim halinde olduğu, bu sebeple; Beyşehir Gölü'nde rekreasyonel tekne taşıma kapasitesinin tek başına hesaplanamayacağı, adalardaki rekreasyon alanlarının ziyaretçi taşıma kapasitesi ile birlikte ele alınması gerektiği düşünülmüştür. $\mathrm{Bu}$ sebeple kara, kıyı, deniz ve göl alanlarına yönelik metodolojilerden faydalanılarak bütünleşik bir yöntem oluşturulmuştur.

Hesapların ilk aşamasında, adalardaki rekreasyon alanlarının anlık kapasiteleri ile adaların çevresindeki göl alanlarının anlık tekne kapasiteleri hesaplanarak eșleștirilmiștir. Anlık kapasite hesapları, teknelerin ada çevresine emniyetli bir şekilde yanaşmaya ve manevra kabiliyetini kısıtlamadan ayrılmaya imkân tanıyan tekne sayısının saptanmasına, ayrıca yürüyüş ve güneş banyosu için ziyaretçilere fiziksel olarak en uygun kullanım alanı sunan maksimum ziyaretçi sayısının belirlenmesine imkân tanımıştır. Eşleştirmede ada çevrelerinde sadece 25 metre boyutlarında teknelerin mola vermesi durumunda; maksimum tekne sayısının adaların anlık ziyaretçi kapasitelerinin üzerinde olduğu saptanmıştır. $\mathrm{Bu}$ eşleştirme, plansız olarak düzenlenecek tekne turlarının, adalardaki rekreasyon alanlarının fiziksel kapasitesinin üzerinde kullanımlara sebep olabileceğini göstermiștir. Ayrıca, rekreasyon alanlarında kalabalığın artarak ziyaretçi memnuniyetinde azalmalara ve doğal kaynak üzerinde baskiya sebep olarak çevresel etkilere sebep olabileceği intimalini göstermiștir. Eşleștirmede farklı uzunluktaki tekneler bir arada düşünülerek, büyüklüklerine göre adaların çevresine fiziksel olarak sığabilen ve yolcu kapasitelerine göre adalardaki rekreasyonel alanların anlık ziyaretçi kapasitelerini aşmayan maksimum tekne sayıları ile ilgili farklı öneriler geliștirilmiștir. Tekne turlarının başlama ve bitiș saatleri, teknelerin her bir adaya varış saatleri ve mola süreleri göz önüne alınarak rotasyon faktörleri saptanmış ve FTK değerleri hesaplanmıştır.

İkinci aşamada ise tekne ile gezinti, yüzme ve güneş banyosu, yürüyüşü kıstllayan veya tamamen engelleyen iklimsel özellikler ile su kuşları açısından hassas olan dönemler belirlenerek GTK hesaplanmıștır. GTK analizleri ile aslında yıl içerisinde tekne turlarına kaç adet ziyaretçinin katılabileceği ve teknelerin yıl içerisinde ortalama olarak kaç defa tura çıkılabileceği tahmin edilmektedir. Bu bağlamda GTK analizlerinin; tekne kapasitesi, sefer sayısı bakım ve işletim masrafları vb. faktörlerin hesaba katıldığ fayda-maliyet analizi kapsamında veri sağlayacağı öngörülmektedir. GTK analizlerinin, Beyşehir Gölü Milli Parkı'nda arz-talep denkleminin içerisinde ve ekolojik sürdürülebilirlik stratejisi ile paralel olarak, tekne turları ile geçimini sağlayan yerel halkın ekonomik acıdan istihdamının sağlanabilmesi yönünde bu sektörün planlı büyümesine katkı sağlayacağı düşünülmektedir.

Üçüncü aşamada ise yönetimce sağlanan mevcut koşullar kapsamında Beyşehir Gölü Milli Parkı'nda yürütülen tekne turu aktivitesinin sürdürülebilmesi yönünde izin verilebilecek maksimum ziyaretçi sayısını ifade eden YK hesaplanmıştır. Yapılan değerlendirmelerde Beyşehir Gölü Milli Parkı'nda parkın mevcut personeliyle kapasitesinin1/3'ü kadar ziyaretçiye hizmet verebileceği sonucuna ulaşılmıștır. Bu durumun Milli Parkın ekonomik sürdürülebilirliğini ve yöre halkının istihdamını olumsuz yönde etkileyebileceği düşünülmektedir.

Sonuçlara göre, Beyşehir Gölü Milli Parkı'nda sürdürülen tekne turu faaliyetleri hesaplanan ETK değerinin altındadır. Ancak, Doğa Koruma ve Milli Parklar 8. Bölge Müdürlüğü tarafindan gerçekleştirilen sürdürülebilir turizm/ekoturizm planları ile yörede turizm faaliyetlerinin artacağı düşunnülmektedir.

Göl ve deniz alanlarında önemli rekreasyonel faaliyetlerden biri olan tekne turlarının ekolojik ve ekonomik yönden sürdürülebilirliğinin, ziyaretçi güvenliği ve memnuniyetinin sağlanması yönünde planlı bir sektörel büyüme için doğru yönetim stratejilerinin belirlenmesi ve uygulanması gerekmektedir. Bu bağlamda tekne turlarının ve turlar kapsamında kullanılan deniz, göl, kıyı ve kara rekreasyon alanlarının bütüncül olarak sürdürülebilir kullanımı yönünde taşıma kapasitesi analizleri planlama çalışmalarının temelini oluşturmaktadır. $\mathrm{Bu}$ sebeple istihdamın büyük bir çoğunluğunun turizm/ekoturizm kaynaklarından sağlandığı korunan alanlarda ve diğer kıyı bölgelerinde, ilgili yasalarca rekreasyon faaliyet planlarının oluşturulmasının ve planlama kapsamında taşıma kapasitesi analizlerinin zorunlu tutulmasının önemli olduğu düşünülmektedir. Bununla birlikte; geliş̧irilen yöntem, tekne turları kapsamında kullanılan rekreasyon alanların fiziksel, iklimsel, ekolojik ve idari özellikleri ile ilişkilidir. Taşıma kapasitesi analizleri tabanlı hazırlanan planların, uygulama sürecinde ekonomik açıdan fayda-maliyet analizlerinin gerçekleştirilmesi, izleme sürecinde göl, deniz, kıyı ve kara ekosistemi üzerindeki ekolojik baskıların ve ziyaretçi memnuniyetinin analiz edilmesi ve elde edilen verilerin sürdürülebilir kalkınma hedefi doğrultusunda yorumlanarak stratejik plan kararlarının alınması ve uygulanması ile başarıya ulaşılabileceği düşünülmektedir.

Ayrıca, bu çalışmada geliştirilen yöntemin bütüncül bir yaklaşım içermesi ve uygulanabilir olması bağlamında geçekleştirilecek benzer çalışmalara referans olabileceği, ayrıca yöntemin ilerideki çalışmalarda balıkçılık, yat turizmi ve dalış turizmi gibi benzer rekreasyonel faaliyetler kapsamında geliştirilebileceği düşünülmektedir.

\section{TESEKKÜR}

Bu çalışma T.C. Orman ve Su İşleri Bakanlığı Doğa Koruma ve Milli Parklar Genel Müdürlügü̈, 8. Bölge Müdürlüğü tarafından desteklenen "Beyşehir Gölü Milli Park1 Sürdürülebilir Turizm /Ekoturizm Planlaması" başlıklı proje kapsamında gerçekleştirilmiştir. 


\section{KAYNAKLAR}

Abu-Hilal, A. H., Al-Najjar, T. 2004. Litter pollution on the Jordanian shores of the Gulf of Aqaba (Red Sea). Marine Environmental Research, 58(1): 39-63.

Adkison, G. P., Jackson, M. T. 1996. Changes in ground-layer vegetation near trails in midwestern US forests. Natural Areas Journal, 16(1):14-23.

Anonim, 2013. Beyșehir Gölü Milli Parkı Sürdürülebilir Turizm/Ekoturizm Planlaması Değerlendirme Raporu. Doğa Koruma ve Milli Parklar 8. Bölge Müdürlüğü, Konya.

Anonim, 2001. Beyșehir Gölü Milli Park1 Uzun Devreli Gelişme Planı Analitik-Etüt Projesi Sonuç Raporu. Hacettepe Üniversitesi, Ankara.

Anonim, 1983. Milli Parklar Kanunu, No:2873. Resmi Gazete Sayı: 18132.

Arnberger, A., Brandenburg, C. 2007. Past on-site experience, crowding perceptions and use displacement of visitor groups to a peri-urban national park. Environ. Manage.;40:34-45.

Bejder, L., Samuels, A., Whitehead, H., Gales, N. 2006. Interpreting short-term behavioural responses to disturbance within a longitudinal perspective. Animal Behaviour, 72(5):1149-1158.

Bosley, H. E. 2005. Techniques for Estimating Boating Carrying Capacity: A Literature Review. Prepared for Catawba-Wateree Relicensing Coalition.

Brouwer, R., Turner, R. K., Voisey, H. 2001. Public perception of overcrowding and management alternatives in a multi-purpose open access resource. Journal of Sustainable Tourism, 9(6):471-490.

Ceballos-Lascuráin H. 1996. Tourism, Ecotourism and Protected Areas: The State of Nature-based Tourism Around the World and Guidelines For Its Development. IUCN Publications, Cambridge.

Cole, D. N. 1987. Effects of three seasons of experimental trampling on five montane forest communities and a grassland in western Montana, USA. Biological Conservation, 40(3):219-244.

Cole, D. N., Bayfield, N. G. 1993. Recreational trampling of vegetation: standard experimental procedures. Biological Conservation, 63(3):209-215.

Crawford, R. E., Stolpe, N. E., Moore, M. J. 1998. The Environmental Impacts of Boating; Proceedings of a Workshop held at Woods Hole Oceanographic Institution, Woods Hole MA USA, December 7 to 9 , 1994 (No. WHOI-98-03). Woods hole oceanographic institution.

Cummins, V., Gault, J., O'mahony, C., Köpke, K., Griffin, P., Walsh, E., O'suilleabhain, D. 2008. Establishing information needs for planning and assessment of recreation activity in the coastal environment: a case study from Cork Harbour, Ireland. In Ireland', Proceedings of the International Pluridisciplinary Conference.
Davenport, J., Davenport, J.L. 2006. The impact of tourism and personal leisure transport on coastal environments: a review. Estuarine and Shelf Science 67:280-292.

Dinsdale, E., Harriott, V. 2004. Assessing anchor damage on coral reefs: a case study in selection of environmental indicators. Environmental Management 33:126-139.

Doshi, S. 2006. Recreational Carrying Capacity in Lakes: How much is too much. Clean Lakes Program, Office of Water Quality, Indiana Department of Environmental Management, Water Column Summer, CP, 18(2).

Manning, R., Valliere, W., Wang, B., Lawson, S., Newman, P. 2002. Estimating day use social carrying capacity in Yosemite National Park. Leisure/Loisir, 27(1-2):77-102.

Falk, J. M., Gerner, P. C. 2002. Maryland coastal bays water-use assessment: understanding users'behaviors, attitudes and perceptions summary of findings. Maryland: Department of Natural Resources.

Farrell, T. A., Marion, J. L. 2001. Trail impacts and trail impact management related to visitation at Torres del Paine National Park, Chile. Leisure/Loisir, 26(12):31-59.

Friedlander, A., Aeby, G., Brainard, R., Brown, E., Chaston, K., Clark, A., Wiltse, W. 2008. The state of coral reef ecosystems of the main Hawaiian Islands. The state of coral reef ecosystems of the United States and Pacific freely associated states, 222-269.

Göktuğ, T.H. 2011. Dilek Yarımadası Büyük Menderes Deltası Milli Parkı'nın Rekreasyonel Taşıma Kapasitesinin Belirlenmesi Üzerine Bir Araştırma. Atatürk Üniversitesi Fen Bilimleri Enstitüsü Peyzaj Mimarlığı Bölümü, Erzurum.

Göktuğ, T. H., Yıldız, N. D., Demir, M., Bulut, Y. 2013. Taşıma Kapasitesi Kuramının Milli Parklarda Oluşum-Gelişim ve Modellenme Süreci. Journal of the Faculty of Agriculture, 44(2):195-206.

Hall, C. M. 2001. Trends in ocean and coastal tourism: the end of the last frontier? Ocean and Coastal Management, 44(9):601-618.

Hall, C. N., Kuss, F. R. 1989. Vegetation alteration along trails in Shenandoah National park, Virginia. Biological Conservation, 48(3):211-227.

Kissling, M., Hegetschweiler, K. T., Rusterholz, H. P., Baur, B. 2009. Short-term and long-term effects of human trampling on above-ground vegetation, soil density, soil organic matter and soil microbial processes in suburban beech forests. Applied Soil Ecology, 42(3):303-314.

Kopke, K., O’Mahony, C., Cummins, V., Gault, J. 2008. Assessment of Coastal Recreational Activity and Capacity for Increased Boating in Cork Harbour. Coastal and Marine Resources Centre Report, University College Cork. 
Kuentzel, W. F., Heberlein, T. A. 2003. More visitors, less crowding: Change and stability of norms over time at the Apostle Islands. Journal of Leisure Research, 35(4):349.

Kuss, R.F., Grafe, A.R. 1985. Effects of Recreation Trampling on Natural Areas Vegetation. Journal of Leisure Research 17: 5-19.

Lawson, S. R., Manning, R. E., Valliere, W. A., Wang, B. 2003. Proactive monitoring and adaptive management of social carrying capacity in Arches National Park: an application of computer simulation modeling. Journal of Environmental Management, 68(3):305-313.

Lawson, S. R., Itami, R. M., Gimblett, H. R., \& Manning, R. E. 2006. Benefits and challenges of computer simulation modeling of backcountry recreation use in the Desolation Lake Area of the John Muir Wilderness. Journal of leisure Research, 38(2):187.

Leon, L. M., Warnken, J. 2008. Copper and sewage inputs from recreational vessels at popular anchor sites in a semi-enclosed Bay (Qld, Australia): estimates of potential annual loads. Marine pollution bulletin, 57(6):838-845.

Lloret, J., Zaragoza, N., Caballero, D., Riera, V. 2008. Impacts of recreational boating on the marine environment of Cap de Creus (Mediterranean Sea). Ocean and Coastal Management, 51(11), 749-754.

Mahoney, E. M., Stynes, D. J. 1995. Recreational boating carrying capacity: A framework for managing inland lakes. East Lansing, MI: Department of Park, Recreation and Tourism Resources, Michigan State University.

Manning, R., Johnson, D., Vande Kamp, M. 1996. Norm congruence among tour boat passengers to Glacier Bay National Park. Leisure Sciences 18, 125-141.

Manning, R., Jacobi, C., Marion, J. L. 2006. Recreation monitoring at Acadia national park. In The George Wright Forum. 23 (2):59-72.

Manning, R., Leung, Y. F., Budruk, M. 2005. Research to support management of visitor carrying capacity of Boston Harbor Islands. Northeastern Naturalist, 12(3):201-220.

Marion, J. L., Leung, Y. F. 2001. Trail resource impacts and an examination of alternative assessment techniques. Journal of Park and Recreation Administration, 19(3):17-37.

Needham, M. D., Szuster, B. W., Bell, C. M. 2011. Encounter norms, social carrying capacity indicators, and standards of quality at a marine protected area. Ocean and Coastal Management, 54(8):633-641.

Nowacek, S. M., Wells, R. S., Solow, A. R. 2001. Short-term effects of boat traffic on bottlenose dolphins, Tursiops truncatus, in Sarasota Bay, Florida. Marine Mammal Science, 17(4):673-688.
Preen, A. 2000. Dugongs, boats, dolphins and turtles in the Townsville-Cardwell region and recommendations for a boat traffic management plan for the Hinchinbrook Dugong Protection Area. Great Barrier Reef Marine Park Authority.

Progressive, A. E. 2005. Little Long Lake-Recreational and Environmental Carrying Capacity Study. Prepared for: Four Township Water Resources Council. Project, (Project No:51830108).

Progressive, A. E. 2001. Four Township Recreational Carrying Capacity Study Pine Lake Upper Crooked Lake Gull Lake Sherman Lake. Prepared for Four Township Water Resources Council, Inc. The Townships of Prairieville, Barry, Richland, and Ross. (Project No: 51830106).

Rajan, B., Varghese, V. M. 2011. Recreational Boat Carrying Capacity of Vembanad Lake Ecosystem, Kerala, South India. Environmental Research, Engineering and Management, 56(2):11-19.

Sayan, M.S., Ortaçeşme, V., Karagüzel, O., Atik, M., Şahin, T., Yıldırım, E., Avcı, Ü. 2005. Termessos (Güllükdağ) Milli Parkı'nda Rekreasyonel Taşıma Kapasitesinin Belirlenmesi. TÜBİTAK Proje No: TOGTAG- 3197, 63s, Antalya.

Shelby, B., Heberlein, T. 1984. A Conceptual Framework for Carrying Capacity Determination. Leisure Sciences. 6: 433-451.

Smallwood, C. B., Beckley, L. E. 2008. Benchmarking recreational boating pressure in the Rottnest Island reserve, Western Australia. Tourism in Marine Environments, 5(4):301-317.

Stankey, G.H. McCool, S.F. 1984. Carrying capacity in recreational settings: Evolution, Appraisal, and Application. Leisure Sciences, 6(4):453-473.

Stewart, W. P., Cole, D. N. 2001. Number of encounters and experience quality in Grand Canyon backcountry: Consistently negative and weak relationships. Journal of Leisure Research, 33(1), 106-120.

Tarrant, M. A., English, D. B. 1996. A Crowding-Based Model of Social Carrying Capacity: Application for Whitewater Boating Use. Journal of Leisure Research, 28(3):155.

Tseng, Y.P., Kyle, G.T., Shafer, C.S., Greafe, A.R., Bradle, T.A., Schuett, M.A., 2009. Exploring the crowding-satisfaction relationship in recreational boating. Environmental Management 43:496-507.

Turner, S. J., Thrush, S. F., Cummings, V. J., Hewitt, J. E., Wilkinson, M. R., Williamson, R. B., Lee, D. J. 1997. Changes in epifaunal assemblages in response to marina operations and boating activities.Marine Environmental Research,43(3): 181-199.

Turner, K., Nielsen, W. (1998). Carrying Capacity of North Lake Leelanau. https://dspace.nmc.edu/handle/11045/24220. 
Valliere, W., Manning R. 2008. Research to support analysis and management of carrying capacity at Lake Umbagog National Wildlife Refuge, Proceedings of the Northeastern Recreation Research Symposium; 2008 March 30-April 1; Bolton Landing, NY. Gen. Tech. Rep. NRS. 2009.

Warnken, J., Dunn, R.J.K., Teasdale, P.R. 2004 Investigation of recreational boats as a source of copper at anchorage sites using time-integrated diffusive gradients in thin film and sediment measurements. Marine Pollution Bulletin 49:833843.

West, E.J., Barnes, P.B., Wright, J.T., Davis, A.R. 2002. Anchors aweigh: fragment generation of invasive Caulerpa taxifolia by boat anchors and its resistance to desiccation. Aquatic Botany, 87:196-202.
Whinam, J., Chilcott, N.M. 1999. Impacts of Trampling on Alpine Environments in Central Tasmania. Journal of Environmental Management 57 (3): 205 220.

Widmer, W.M., Underwood, A.J. 2004. Factors affecting traffic and acnchoring patterns of recreational boats in Sydney Harbour, Australia. Landscape and Urban Planning 66:173-183.

Yıldırım U.B., Tuğrul-İçemer, G. 2010. Kabul edilebilir Değişiklik Sınırları (LAC) Modeli ile Phaselis Koyu Fiziksel Taşıma Kapasitesinin Belirlenmesi. VIII. Türkiye'nin Kıyı ve Deniz Alanları Ulusal Kongresi, 27 Nisan -01 Mayıs 2010, 77-88. 